GENERAL REVIEW OF THE SURVEY'S ACTIVITIES IN 1968

The Geological Survey of Greenland continued in 1968 to carry out its three main tasks - the geological mapping of Greenland, the investigation of mineral deposits of economic interest and the publication of results. In addition the Survey has acted as geological adviser to the Ministry for Greenland in matters concerning the granting of mineral exploration concessions.

\title{
Geological mapping
}

Three categories of geological maps are being prepared at present by the Survey.

1) Regional maps at scales $1: 500000$ and $1: 2500000$

2) Survey map sheets at scale $1: 100000$

3) Detailed maps of selected areas

Regional maps

A five-year programme for the preparation of regional geological maps of West Greenland at 1:500 000 was begun in 1964. The mapping is now so far advanced that the first sheet (Sфndre Str $\phi$ mfjord - Nûgssuaq) can be published in 1969. It is planned that three more sheets will be published in the following years at the rate of one a year.

A new geological map of Greenland at 1 : 2500000 has been prepared and the printing will take place in 1969. The final draught of the map was displayed at the $23 \mathrm{rd}$ International Geological Congress at Prague, August 1968.

The Survey is also collaborating in the production of a metallogenic map of North America which will include Greenland, and is completing the part of the 1: 1500000 Geological Map of Eur,ope which covers Greenland.

Survey sheets at $1: 100000$

Map sheets at $1: 100000$ are the main repository for the results of field mapping in Greenland. The map sheet Ivigtut was printed in 1968 , 
the Mârmorilik sheet is in press and the sheets Nûgâtsiaq, Pangnertôq and Julianehåb are completed in manuscript form. The sheet Agatdal will probably be finished in 1969 and the sheets Qutdligssat, Midternæs, Neria, Narssarssuaq and Nanortalik are being draughted. The field work on the sheets Nerutussoq and Nigerdlikasik was completed in 1968.

\section{Economic-geological investigations}

The act on mineral resources in Greenland was passed by the Danish Government in 1965. It is the policy of the act to stimulate private prospecting initiative in Greenland. Accordingly the Survey has assisted several private companies which have exploration concessions in Greenland. The companies have been provided with maps and information from areas in which they are working. The Survey has also been in correspondence with a number of foreign companies concerning economic possibilities in Greenland. As a result of these efforts 11 different concessions have been granted since 1965. Most of the concessions given are for areas in West Greenland.

The Survey has continued routine studies of various potential mineral resources e.g. uranium, beryllium and niobium in the Ilímaussaq intrusion near Narssaq. This work is carried out in close cooperation with the Atomic Energy Commission's Research Establishment at Ris $\phi$.

Furthermore studies of the chromium ore deposits at Fiskenæsset have been continued. A report on the bituminous shales of Nugssuaq and their geological setting is in preparation and is expected to be published early in 1969.

Apart from these special studies records of mineralisations have been kept in the course of the regional field mapping.

The director of the Survey has as government representative in the Board of Nordisk Mineselskab A/S contributed to the planning of the prospecting activity of this company.

Quaternary geology

It has been decided that the $1: 2500000$ geological/tectonic map of Greenland and the 1 : 500000 sheets of West Greenland should be supplemented by maps of the Quaternary at the same scales. It is planned that a finished manuscript map of the Quaternary at $1: 2500000$ should be exhibited at the 


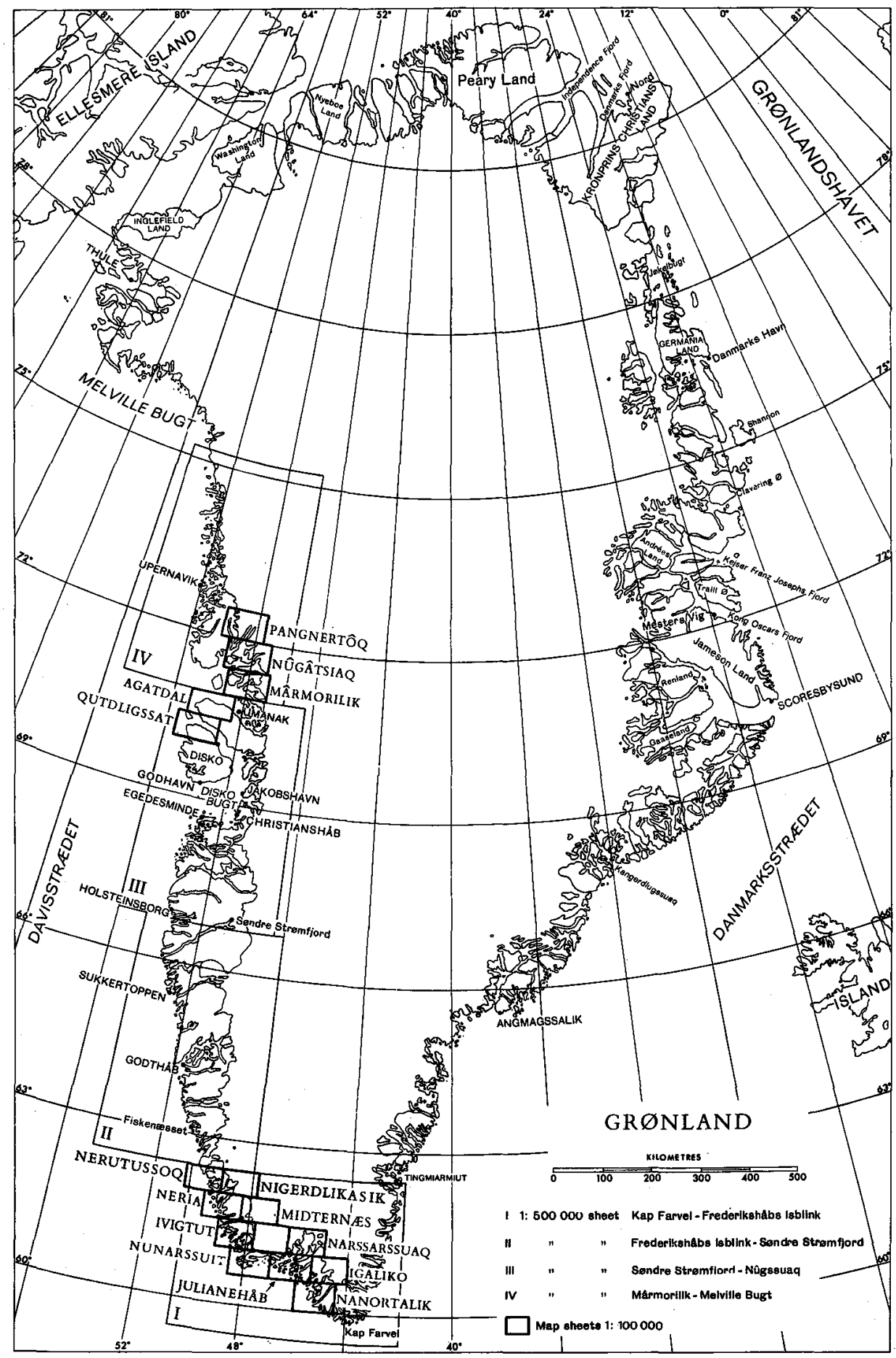


INQUA congress in 1969 and published in 1970. Draughting of this map has begun.

As a step towards the preparation of 1 : 500000 maps an investigation of moraines and former sea levels in the Nordre Strømfjord area was carried out in 1968.

As part of the Scoresby Sund expedition (see below) a study of velocity and production of some of the glaciers in this area was begun.

The study of permafrost in West Greenland was continued. Two more stations for ground temperature measurements have been set up, at Godhavn and Jakobshavn. The new stations bring the total number of permafrost stations to six.

\section{Expeditions}

In all 116 persons were sent to Greenland in 1968. The majority worked, as in previous years, in West Greenland, where the main activity was concentrated in the Frederikshåb district. As a new project the first of a series of larger expeditions to East Greenland was sent to the Scoresby Sund area. Here it is planned to attempt the mapping of about $60000 \mathrm{~km}^{2}$ of unknown country in the course of five seasons. In 1968 twelve two-man geological parties were sent into the fjord complex, where operations were based on m/s "Martin Karlsen" (formerly "Kista Dan"). The parties were supported by two helicopters which operated from the ship's two heliplatforms. The brief, six-week long field season was utilised in a highly efficient manner, in that both the logistics and the stable weather favoured geological work, so that work planned was carried out in full.

Aerial photography was carried out in both East and West Greenland in 1968 by the Geodetic Institute in collaboration with the Survey. Much of Greenland is covered by satisfactory vertical and oblique aerial photographs. However, in most of the Scoresby Sund fjord complex only oblique aerial photographs have been available, and due to the extreme relief it was impossible to complete the topographic map on the basis of these alone. Vertical photographs were necessary for this as well as very important for the geological mapping. Therefore the Survey sought through grants to support the Geodetic Institute's efforts to carry out the vertical photography necessary for completion of this map, and also to carry out vertical aerial 
photography in the Fiskenæsset region in West Greenland, where the Survey's main activity in West Greenland will be concentrated in coming years, and where the existing vertical photographs were taken at a time when snow cover obscured all geological detail in the higher ground. The project is not yet completed, and it is intended to continue with aerial photography in 1969.

Collaboration with other institutes

The Survey has continued to maintain a close contact with a large number of other institutes, both Danish and foreign, in order to benefit from the sharing of resources and the exchange of ideas. In keeping with this policy the Survey has in the past year collaborated with the MineralogicalGeological Institutes and Mineralogical Museum of the University of Copenhagen, the Danish Atomic Energy Commission, and the Geological Institute of the University of Arhus. Furthermore the Survey field team was joined in 1968 by geologists from the universities of Basel, Lausanne, Modena, Uppsala, Exeter, Lancaster and London, and Portsmouth College of Technology.

Samples of basic dykes from West Greenland have been sent to the Geological Survey of Canada for dating. The Geochronology Section of the Geological Survey of Canada is carrying out an age study of regional swarms of basic dykes in Canada. By extending the scope of the study to include Greenland, which is an extension of the Canadian shield, a more comprehensive account of these dykes can be given.

Further cooperation with the Geological Survey of Canada is planned for 1969 when a geologist from the Geological Survey of Greenland will join the GSC field party working on the north-east coast of Labrador, directly opposite the best known part of Greenland.

Two geologists participated on behalf of the Survey in Count Eigil Knuth's 5th Danish Peary Land Expedition, and one Survey glaciologist accompanied the South Greenland expedition of the Academy of Sciences of the USSR.

Much of the work in Greenland forms not only part of the Survey mapping programme but also a contribution to various international research projects. Work has continued on projects forming part of the Danish 
programme for the International Upper Mantle Project (see the International Union of Geological Sciences circular no. 12, p. 58) and UNESCO's International Hydrological Decade.

Organisation and personnel

The permanent scientific staff of the Survey in 1968 consisted of 16 geologists and 1 chemist. During the field season this team was supplemented by 27 geologists from other institutions (see above) and 25 senior students. The permanent supporting staff in Copenhagen numbers 22; this figure is relatively low due to the sharing of many facilities with the MineralogicalGeological Institutes and Mineralogical Museum. The total number of participants (geologists and supporting staff) in the summer expeditions was 116 together with 26 Greenlanders.

The Survey's field programme was much more extensive in 1968 than in previous years, but the permanent staff has not been increased. This is due mainly to the restricted conditions in the institute in Copenhagen. In spite of more administrative work than before the staff has managed to fulfil all the commitments given under the Survey's programme.

Plans for improvement have been successful and the Survey is preparing to move to another building ( $\varnothing_{\text {stervoldgade } 10)}$ in the spring of 1969.

K. Ellitsgaard-Rasmussen

Director 